\title{
PERENCANAAN LANSEKAP MASJID DARUL IHSAN BEKASI DENGAN PENDEKATAN TEKNIK TAMAN VERTIKAL
}

\author{
Diah Anggraini ${ }^{1}$, Mieke Choandi ${ }^{1}$, Joni Chin ${ }^{1}$ dan Franky Liauw ${ }^{1}$ \\ ${ }^{1}$ Jurusan Arsitektur FT Universitas Tarumanagara \\ Email:diaha@ft.untar.ac.id \\ Email: miekec@ft.untar.ac.id \\ Email:frankyl@ft.untar.ac.id \\ Email: jonic@ft.untar.ac.id
}

\begin{abstract}
ABSTRAK
Kecukupan ruang terbuka hijau sangat penting bagi suatu kota karena penghijauan mempunyai fungsi - fungsi ekologis, sosial dan ekonomis yang terkait dengan kualitas kehidupan warganya. Namun seiring dengan meningkatnya jumlah penduduk berikut kegiatannya, semakin berkurang pula ketersediaan lahan untuk penghijauan kota. Salah satu solusi yang dapat digunakan untuk meningkatkan kuantitas area penghijauan adalah melibatkan warga untuk menanam di pekarangannya walaupun luasannya terbatas dengan teknik bertanam vertikal. Tulisan ini merupakan hasil kajian dalam rangka penyusunan rencana lansekap Masjid Darul Ihsan, Pondok Pekayon Indah, Bekasi yang saat ini sangat dominan area perkerasannya, melalui kegiatan Pengabdian Kepada Masyarakat (PKM). Studi ini menghasilkan rancangan lansekap di lahan yang terbatas area tanamnya, berikut percontohan cara bertanam vertikultur yang ditujukan untuk menambah wawasan bagi warga sekitar (melalui penyuluhan) tentang penghijauan pekarangan yang ramah lingkungan, terutama dalam proses daur ulang air wudhu dan pemanfaatan limbah plastik.
\end{abstract}

Kata Kunci: lansekap, masjid, pekarangan, vertikultur

\section{PENDAHULUAN}

Meningkatnya kepadatan penduduk terutama di kawasan perkotaan berdampak pada semakin berkurangnya lahan untuk penghijauan. Demikian pula luas pekarangan rumah pada berbagai kawasan perumahan di perkotaan, menjadi semakin sempit dengan semakin meningkatnya intensitas kepadatan bangunan dan kepadatan kota. Padahal kecukupan ruang terbuka hijau sangat penting bagi suatu kota karena fungsi-fungsi ekologis, sosial dan ekonomis yang disandang olehnya. Peningkatan upaya penghijauan kota-kota di Indonesia umumnya sering dikalahkan karena pertimbangan yang lebih mementingkan peningkatan pembangunan fisik berbagai sarana dan prasarana perkotaan yang lain. Hal ini seringkali menyebabkan luasan RTH semakin menurun, yang disadari maupun tidak, kemudian disertai penurunan kualitas lingkungan hidup warga kotanya. Mempertahankan zona hijau dengan melakukan penghijauan/gerakan hijau pada dasarnya dapat memperbaiki kualitas lingkungan dan kehidupan mahluk hidup. Menurut Purnomo Hadi (2007), penghijauan di pekarangan/halaman rumah/bangunan privat tetap dapat membantu meningkatkan kualitas fisik lingkungan di kawasan perkotaan terutama pada area dengan kepadatan bangunan yang relatif tinggi.

Tulisan ini merupakan hasil kajian dalam rangka penyusunan rencana lansekap Masjid Darul Ihsan, Pondok Pekayon Indah, Bekasi melalui kegiatan Pengabdian Kepada Masyarakat (PKM).

Selain untuk kegiatan peribadatan, Masjid Darul Ihsan ini menjadi wadah untuk menyelenggarakan pelayanan bagi masyarakat sekitar dalam bentuk penyediaan fasilitas: TPA (Taman Pendidikan Al Quran), perpustakaan, ruang sekretariat, parkir mobil dan motor jemaah, serta ruang terbuka semi publik. Mengingat beragamnya kegiatan yang berlangsung di lingkungan Masjid tersebut, maka dirasa perlu untuk menata lansekap yang selain dapat mendukung penyelenggaraan kegiatan di masjid, juga ditujukan untuk menambah wawasan bagi warga sekitar tentang penghijauan pekarangan, dan diharapkan dapat mendorong warga untuk 
meningkatkan upaya penghijauan lingkungan yang dimulai dari pekarangan rumah masingmasing.

\section{TINJAUAN PUSTAKA}

\section{Taman Dalam Islam}

Taman menurut Islam ditujukan untuk menciptakan tempat tenang untuk istirahat, untuk merefleksi diri dan mengingatkan manusia tentang surga. Referensi tentang taman banyak ditulis dalam Al Qur'an yang umumnya digunakan sebagai gambaran kehidupan di surga, sebagaimana yang dijanjikan Allah bagi orang-orang yang beriman. Beberapa taman yang terkenal di dunia dan masih dapat disaksikan hingga saat ini antara lain Taj Mahal di India, Generalife dan Alhambra di Spanyol. Tema umum pada taman-taman Islam adalah air dan shading/pembayangan. Hal ini dapat dipahami mengingat Islam lahir dan menyebar pada kawasan yang beriklim panas kering dan kurang subur. Berbeda dari taman-taman di daratan Eropa yang sering didesain untuk berjalan-jalan, taman dalam Islam lebih ditujukan untuk istirahat dan kontemplasi. Secara umum Muslim mempunyai beberapa bentuk taman sesuai dengan tujuannya, antara lain (1) bustan yaitu taman yang berfungsi sebagai inner court suatu rumah, biasanya merupakan taman formal dengan kolam dan air mancur (gambar 1 dan 2) ; (2) jannah adalah kebun buah-buahan dengan palem jeruk dan vines yang dilengkapi kanal-kanal untuk irigasi; dan (3) rawdah mengacu pada kebun sayur-sayuran yang berfungsi memproduksi bahan makanan (disarikan dari Wikipedia. Islamic garden en.m.wikipedia.org 2015).
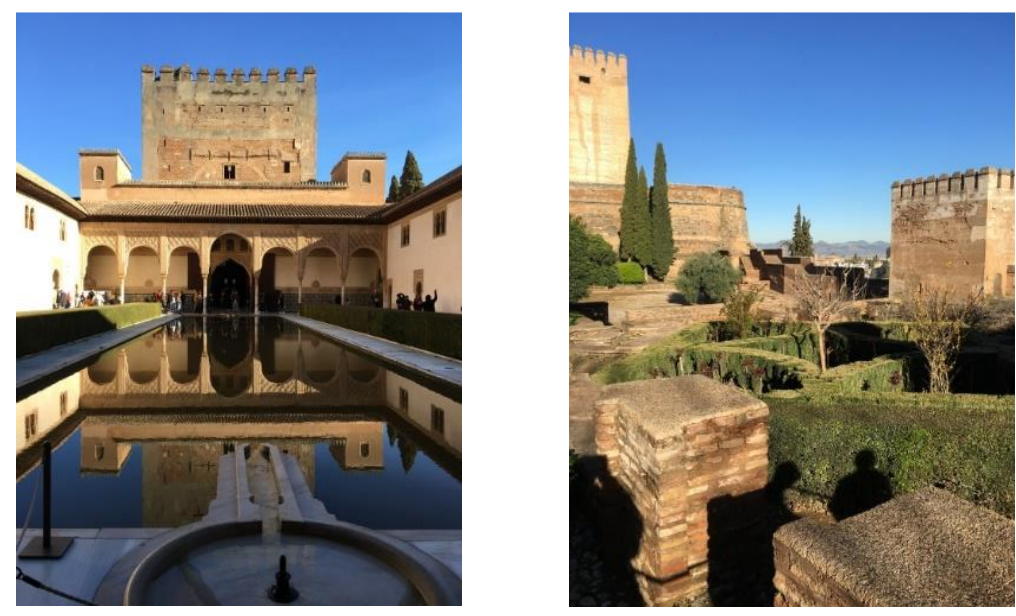

Gambar 1. Istana Raja Ismail 1, Alhambra, Granada menerapkan unsur air dan pembayangan. Gambar 2. Taman di Alhambra, Granada, taman sebagai tempat kontemplasi.

(Sumber: Dokumentasi pribadi)

\section{Pekarangan Sebagai Cikal Bakal Budaya Hijau Oleh Masyarakat.}

Menurut E. Hahn, Van der Kolf Lekkerberker (dikutip dari Thohir 1985), bentuk pertanian yang pertama-tama dilakukan manusia ialah bercocok tanam di atas tanah kering di sekitar rumah atau tempat tinggal. Fenomena ini meluas ke berbagai belahan dunia. Di Indonesia meluasnya budaya bercocok tanam di lahan sekitar rumah yang ditanami dapat ditandai dari beragamnya istilah misalnya: pekarangan (Jawa), parak (Minangkabau), karang (Bali), pamengkang (Pamekasan), poan (Timor), paljangan (Banyumas), tegalan (Pekalongan), bojong (Semarang), sanggam (Besuki), karangkitri (Surabaya), dan sebagainya.

Terkait dengan fungsi-fungsi ekologis penghijauan secara umum, pada dasarnya penghijauan di pekarangan tetap dapat membantu meningkatkan kualitas fisik lingkungan di kawasan 
perkotaan dengan kepadatan bangunan yang relatif tinggi. Menurut Thohir (1985) pekarangan selain memiliki fungsi beraneka ragam, juga memiliki keanekaragaman jenis tanaman, sehingga wajah dari budidaya pekarangan dapat dinamakan pertanaman yang bersifat polykultur. Pekarangan mempunyai fungsi hydro-orologis, karena bentuk lahannya datar, sehingga umumnya erosi rendah. Kemudian karena susunan tanaman di pekarangan biasanya padat bertingkat-tingkat, kecepatan dan kekerasan jatuhnya air hujan juga tertahan sehingga permukaan tanah tidak mudah rusak. Lapisan humusnya yang berasal dari seresah dedaunan cukup baik. Siklus limbah tanaman dapat tetap berlangsung, misalnya sisa-sisa dedaunan untuk memberi makan hewan (ayam, angsa), sedang kotoran hewan dapat digunakan untuk pupuk.

\section{Manfaat Penghijauan Untuk Kawasan Perkotaan}

Dalam skala yang lebih luas yaitu kota, manfaat yang dapat dirasakan dari penghijauan kota (disarikan dari Susatyo, 2007) antara lain meliputi: (1) manfaat estetika, atau keindahan; (2) manfaat orologis, untuk mengurangi tingkat kerusakan tanah; (3) manfaat hidrologis sebagai daerah persediaan air; (4) manfaat klimatologis karena efek rumah kaca akan dikurangi oleh banyaknya tanaman dalam suatu daerah; (5) manfaat edaphis yang berhubungan erat dengan lingkungan hidup satwa di perkotaan; dan (6) manfaat ekologis, karena terkait dengan kehidupan makhluk di alam yang saling ketergantungan.

Selain itu penghijauan juga mempunyai manfaat edukatif, mengingat semakin langkanya pepohonan yang hidup di perkotaan membuat sebagian warganya tidak mengenal lagi berbagai jenis vegetasi. Vegetasi juga dapat memberi manfaat protektif, karena pepohonan dapat menjadi pelindung dari teriknya sinar matahari di siang hari, pelindung dari terpaan angin kencang dan peredam dari suara kebisingan serta manfaat hygienis, terutama kemampuan pepohonan untuk menetralisir polutan. Bahkan tanaman juga mampu menghasilkan gas oksigen yang sangat dibutuhkan manusia.

\section{Teknik Bertanam Vertikultur}

Mengingat terbatasnya lahan Masjid Darul Ihsan yang dapat ditanami, maka dipilih teknik bertanam secara vertikal. Menurut Morrison S. \& Sweet R., metode ini mengacu pada konsep taman tegak, yaitu tanaman dan elemen lainnya diatur sedemikian rupa pada sebuah bidang tegak lurus sebagai taman dalam waktu yang relatif lama. Sistem yang meletakkan tanaman pada dinding dan struktur bangunan ini bisa sekaligus sebagai penghijauan pada fasad bangunan baik sebagian maupun secara keseluruhan.

Teknik vertikultur dapat dilakukan di dalam maupun di luar ruangan dan dipandang cocok untuk daerah perkotaan yang umumnya menghadapi keterbatasan lahan. Selain itu, pertanian vertikultur tidak hanya sebagai sumber pangan, tetapi juga dapat menciptakan suasana alami yang menyenangkan (Lukman, 2018). Sistem taman vertikal ini yang sering disebut dengan vertical garden, dinding hidup, bio walls dan eco walls, merupakan metode bercocok tanam pada lahan yang sempit dan terbatas dengan menggunakan dinding atau ruang secara vertikal dengan menutupinya dengan tumbuhan yang hidup di atas media tanam (Sumber: https://id.wikipedia.org/wiki/Kebun_vertikal). Green wall merupakan nama lain dari vertical garden yang digunakan untuk merujuk kepada semua bentuk vegetasi yang terdapat pada permukaan dinding (Green Roof Organization, 2008 dalam Ozyavuz, 2013: 587). Menurut Damastuti, (dalam Kusmiati dan Solikhah 2015), kelebihan teknik vertikultur antara lain: (1) efisiensi penggunaan lahan karena yang ditanam jumlahnya lebih banyak dibandingkan sistem konvensional; (2) penghematan pemakaian pupuk dan pestisida; (3) kemungkinan tumbuhnya rumput dan gulma lebih kecil; (4) dapat dipindahkan dengan mudah karena tanaman diletakkan pada wadah tertentu; (5) mempermudah monitoring dan pemeliharaan tanaman; dan (6) adanya atap plastik memberi keuntungan mencegah kerusakan karena hujan, menghemat biaya 
penyiraman karena atap plastik mengurangi penguapan. Sedang kelemahan teknik ini adalah: (1) rawan terhadap serangan jamur, karena kelembaban udara tinggi akibat tingginya populasi tanaman dalam plastik; (2) investasi awal cukup tinggi; (3) sistem penyiraman harus kontinyu; dan (4) diperlukan beberapa peralatan tambahan, misalnya tangga sebagai alat bantu penyiraman.

\section{Pemilihan Tanaman dan penempatannya.}

Seleksi tanaman dan penempatannya merupakan faktor penting dalam perencanaan lansekap. Hasil studi yang dilakukan oleh Tan et.al. (2017) menunjukkan pentingnya konteks dan lokalitas. Bangunan yang berdekatan akan mempengaruhi paparan radiasi matahari secara signifikan, dan selanjutnya akan memengaruhi proses penempatan tanaman. Selain itu, setiap jenis tanaman/pohon mempunyai kelebihan serta kekurangannya sendiri. Salah satunya sampah pohon, karena daun, bunga ataupun buah pohon memiliki tingkat kerontokannya masing-masing. (Cut Anissa, 2018). Kekurangan lainnya adalah kerusakan konstruksi jalan/perkerasan akibat sistem perakaran pohon, meskipun hal ini bisa diatasi dengan pengaturan teknis penanamannya.

Terkait dengan pemilihan tanaman, Lukman (2018) mengatakan bahwa komoditas yang ditanam dengan teknik vertikultur sebaiknya disesuaikan dengan kebutuhan, memiliki nilai ekonomis tinggi, berumur pendek dan berakar pendek, seperti selada, kangkung, bayam, pokcoy, caisim, katuk, kemangi, tomat, pare, kacang panjang, mentimun dan sebagainya. Selain itu perlu dipertimbangkan tujuan pembuatan budidaya vertikultur. Jika untuk tujuan komersial perlu dipertimbangkan aspek ekonomisnya. Agar biaya produksi jangan sampai melebihi pendapatan dari hasil penjualan tanaman. Sedangkan jika untuk hobi, vertikultur dapat dijadikan sebagai media kreativitas, sekaligus mendapatkan sayur sehat dan berkualitas untuk kebutuhan dapur ataupun sebagai tanaman obat keluarga (TOGA).

\section{METODE PELAKSANAAN PKM}

\section{Identifikasi Area Lahan Terbuka.}

Masjid Darul Ihsan berdiri di atas lahan seluas 1098,67 m2, dengan area terbangunnya sekitar 185,88 m2, sehingga masih terdapat lahan terbuka seluas 912,79 m2. Namun sebagian besar pekarangan masjid telah diberi perkerasan, untuk selasar, teras, ramp untuk pengguna kursi roda, dan bentuk perkerasan lainnya, sehingga hanya tersisa sedikit tanah asli yang dapat ditanami. Hal tersebut dapat dilihat pada Gambar 3 dan 4 yang menjelaskan kondisi halaman masjid yang dijadikan area penataan lansekap, baik area terbuka dengan potensi penyinaran matahari maksimal maupun area yang hanya mempunyai potensi penyinaran matahari terbatas (pada siang hari antara pk 10.00 - $14.00 \mathrm{WIB}$ ) karena posisinya berada pada daerah bayangan bangunan atau area terkena bayangan pepohonan. Sehingga pemilihan tanaman akan mempertimbangkan jenis yang memang memerlukan penyinaran matahari sempurna ataupun yang kurang membutuhkan sinar matahari.
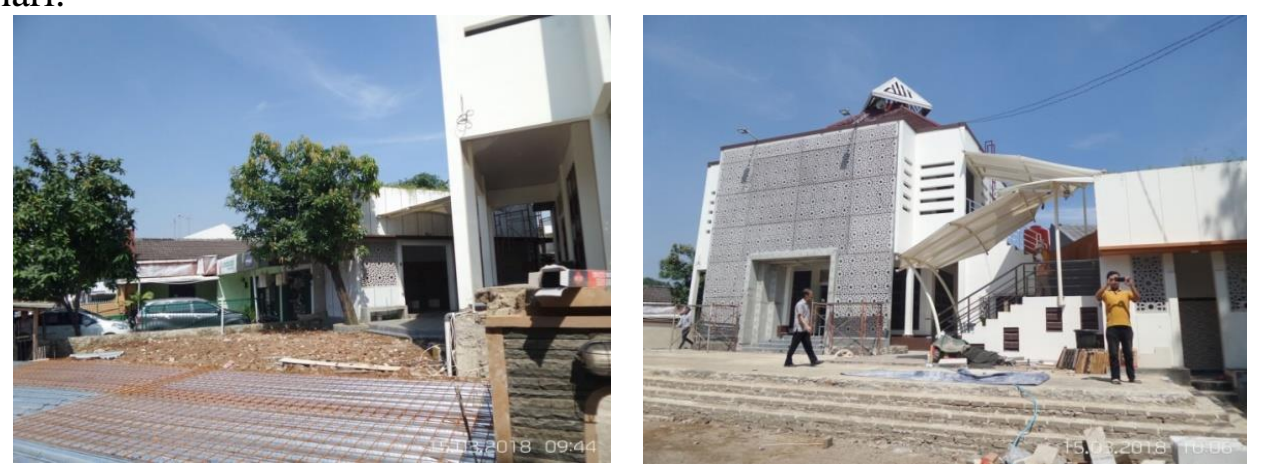

Gambar 3 dan 4. Halaman dan Ruang Terbuka di Masjid Darul Ihsan (Sumber: dokumenntasi pribadi) 


\section{Identifikasi Area Tanam}

Selain di lahan terbuka horizontal, area tanam bisa dilakukan pada bidang dinding vertikal dengan system vertical planting. Berdasar hasil identifikasi pada tapak disimpulkan bahwa selain area horizontal, terdapat banyak bidang-bidang vertikal yang potensial untuk dijadikan area tanam seperti dinding dan pagar pembatas tapak (Gambar 5). Pemilihan jenis tanaman akan disesuaikan dengan kondisi area tanam yang memungkinkan, dan akan mengutamakan jenis tanaman produktif, selain mempunyai fungsi estetis dan ekologis (Gambar 6)

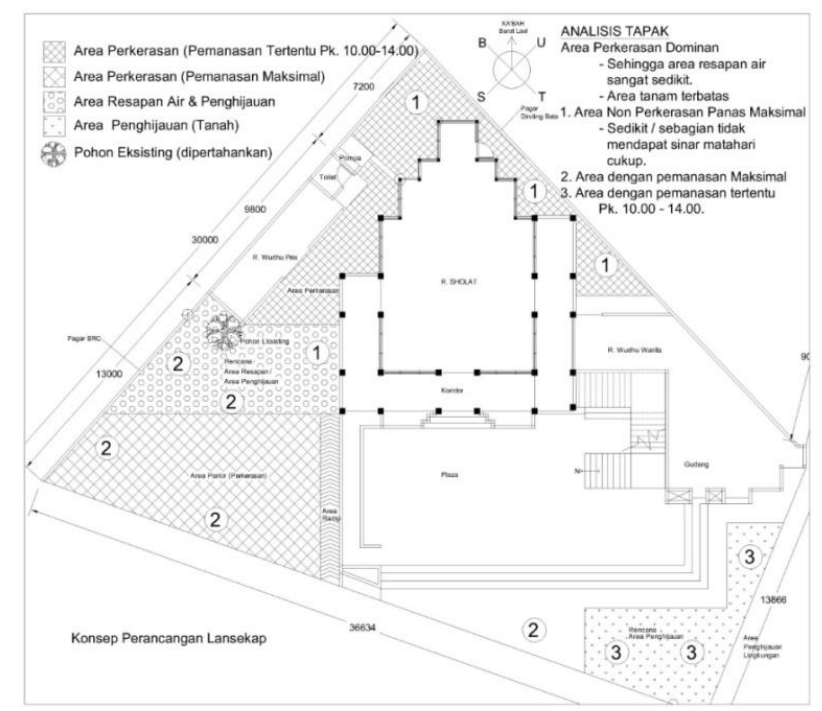

Gambar 5. Identifikasi Area Tanam pada Tapak (Sumber: dokumentasi pribadi)

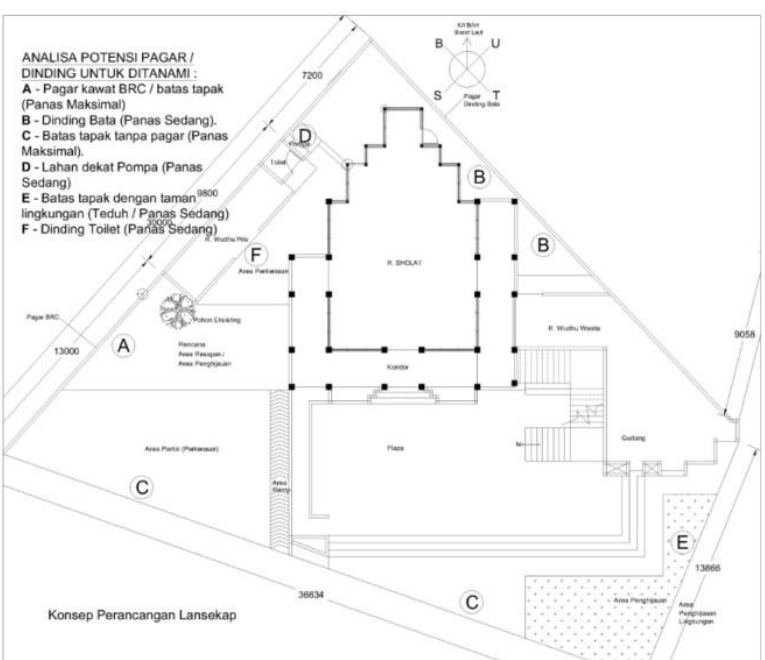

Gambar 6. Analisis Potensi Pagar/Dinding Sebagai Area Tanam

(Sumber: dokumentasi pribadi)

\section{Tinjauan Kegiatan di Masjid Darul Ihsan}

Sebagaimana masjid di Indonesia pada umumnya, kegiatan di Masjid Darul Ihsan terdiri dari: 
- Kegiatan rutin/harian: meliputi kegiatan ibadah sholat 5 waktu yang dilakukan berjamaah maupun perorangan, sholat Jumat berjamaah, kegiatan pengajian, TPA (Taman Pendidikan Al Qur'an), majelis taklim, kuliah subuh, serta kegiatan kepengurusan masjid.

- Kegiatan berkala meliputi: rangkaian kegiatan di bulan Ramadhan (sholat tarawih berjamaah, sholat Idul Fitri, penerimaan dan penyaluran zakat fitrah/zakat mal/infaq, sodakoh dan sebagainya), serta rangkaian kegiatan Idul Adha (sholat Ied berjamaah di halaman masjid, penerimaan, pemeliharaan, penyembelihan dan penyaluran hewan kurban yang umumnya terdiri dari sapi, kerbau dan kambing ). Selain itu Masjid Darul Ihsan juga secara berkala melaksanakan kegiatan peringatan hari-hari besar Islam, antara lain Isra Mi'raj dan Maulud Nabi, yang biasanya diisi dengan kegiatan pengajian, ceramah agama dengan pengunjung yang lebih banyak dibandingkan pada acara rutin.

\section{Konsep Perancangan Lansekap Masjid}

Sesuai dengan kegiatan masjid yang bervariasi khususnya pada waktu-waktu seperti di bulan Ramadhan dan Idul Adha, serta kegiatan insidentil lainnya, misalnya peringatan hari-hari besar Islam, maka dituntut penyelesaian kreatif yang menekankan pada fleksibilitas dari berbagai elemen penunjang masjid, salah satunya adalah penghijauan. Berdasar kegiatan masjid tersebut maka pertimbangan dalam desain lansekap adalah sebagai berikut:

- Diperlukan penataan lansekap yang dapat mendukung kegiatan baik harian, kegiatan berkala, maupun insidentil.

- Untuk kegiatan rutin/harian, perletakan tanaman diutamakan pada area yang tidak mengganggu pelaksanaan ibadah dan kegiatan rutin, dan dapat ditanam di lahan tanah/ tanpa perkerasan. Dapat pula tanaman pot/polybag yang diletakkan pada rak-rak yang permanen.

- Mengingat area tanam terbatas maka prinsip penataan lansekap masjid diutamakan pada penyediaan media dan pot tanaman yang mobile, dapat dipindahkan pada saat-saat tertentu, ketika diperlukan space lebih luas untuk ibadah sholat berjamaah di halaman masjid atau area untuk pemeliharaan, penyembelihan dan pembagian hewan kurban saat Idul Adha.

Setelah memperhatikan hasil analisis tapak dan kondisi area tanam, maka rencana penataan lansekap Masjid ini akan didasarkan pada konsep sebagai berikut:

1. Memanfaatkan secara maksimal area/lahan tanpa perkerasan untuk fungsi resapan air, dan peluang untuk menanam pohon pelindung bertajuk rimbun untuk fungsi memperbaiki kualitas iklim lokal.

2. Mengutamakan pemilihan tanaman produktif yang dimaksudkan untuk percontohan bagi warga sekitar agar termotivasi berkebun dengan cara organik, selain hasilnya dapat dimanfaatkan oleh Masjid.

3. Memilih tanaman yang sesuai dengan kondisi area tanam, terutama dalam perolehan penyinaran matahari.

4. Memilih tanaman yang mudah dan murah dalam perawatan.

5. Menggunakan prinsip recycle, khususnya memanfaatkan air bekas wudhu, sehingga menghemat air untuk perawatan dan penyiraman tanaman dan reuse barang bekas untuk wadah tanam/pot.

\section{HASIL DAN PEMBAHASAN}

\section{Hasil Pelaksanaan Kegiatan PKM}

Pelaksanaan kegiatan PKM Perencanaan Lansekap Masjid Darul Ihsan ini menghasilkan: gambar desain lansekap Masjid Darul Ihsan (Gambar 7 dan 8). Selain itu kegiatan PKM ini juga membuat rak tanaman vertikultur sebagai proyek percontohan bagi pengelola dan masyarakat 
sekitar masjid (gambar 9, 10 dan 11). Prinsip pembuatan taman vertikal ini memanfaatkan barang-barang bekas pakai seperti botol minuman kemasan, sehingga ekonomis dan ramah lingkungan. Teknik vertikultur ini menggunakan suplai air dari dua sumber, yaitu dari sisa wudhu dan saat tandon air sisa wudhu kosong dapat mengambil dari tangki air. Air dipompa ke atas kemudian disalurkan dengan menggunakan selang ke pot-pot tanaman yang tergantung secara vertikal. Untuk menjamin penyiraman yang teratur, dan penggunaan daya listrik yang hemat, pompa dihubungkan ke timer/pengatur waktu penyiraman. Dalam hal ini digunakan pompa akuarium dengan daya listrik 60 watt, yang mampu menyalurkan air setinggi 2.8 meter. Selain itu dibuat juga tanaman dalam pot, karena dinilai cukup efektif untuk tanaman buahbuahan, dan bersifat fleksibel karena mudah digeser atau dipindahkan ketika halaman masjid diperlukan untuk kegiatan ibadah seperti sholat Ied dan kegiatan pemotongan hewan saat Idul Adha. Jenis vegetasi dipilih tanaman yang cukup mudah dirawat dan tahan cuaca seperti: jahe merah, cabai Jepang, dan pandan. Jahe merah berguna sebagai tanaman obat keluarga, pandan sebagai pewangi makanan dan cabai Jepang sebagai penyedap makanan.

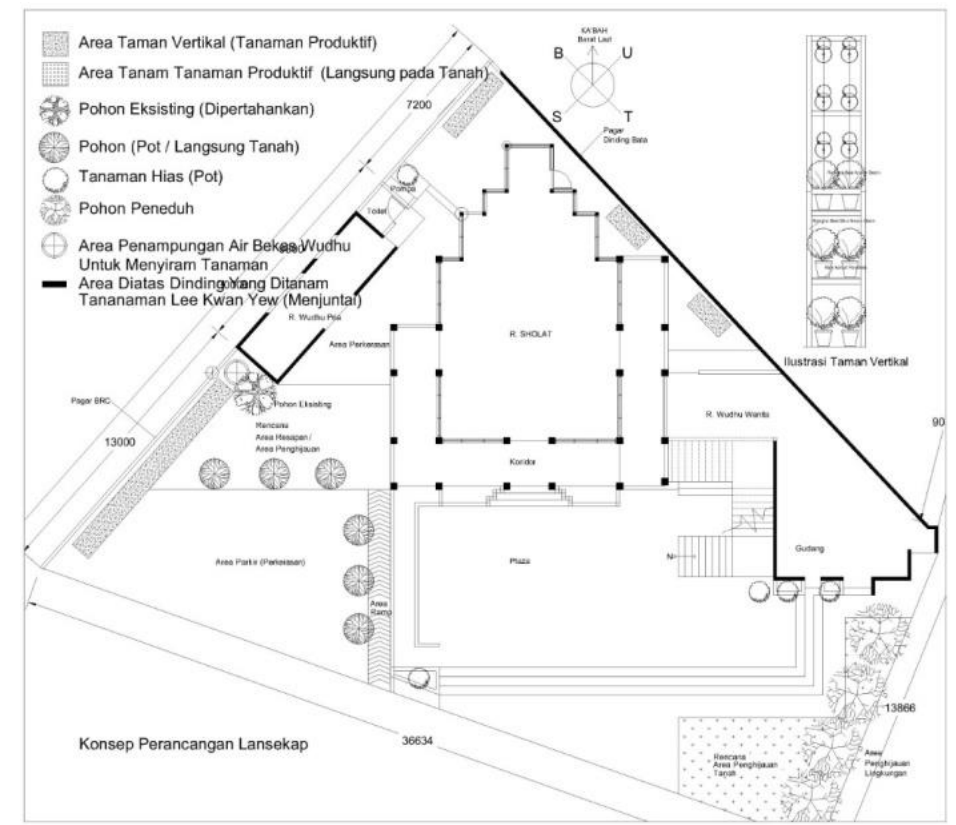

Gambar 7. Konsep Penataan Lansekap 


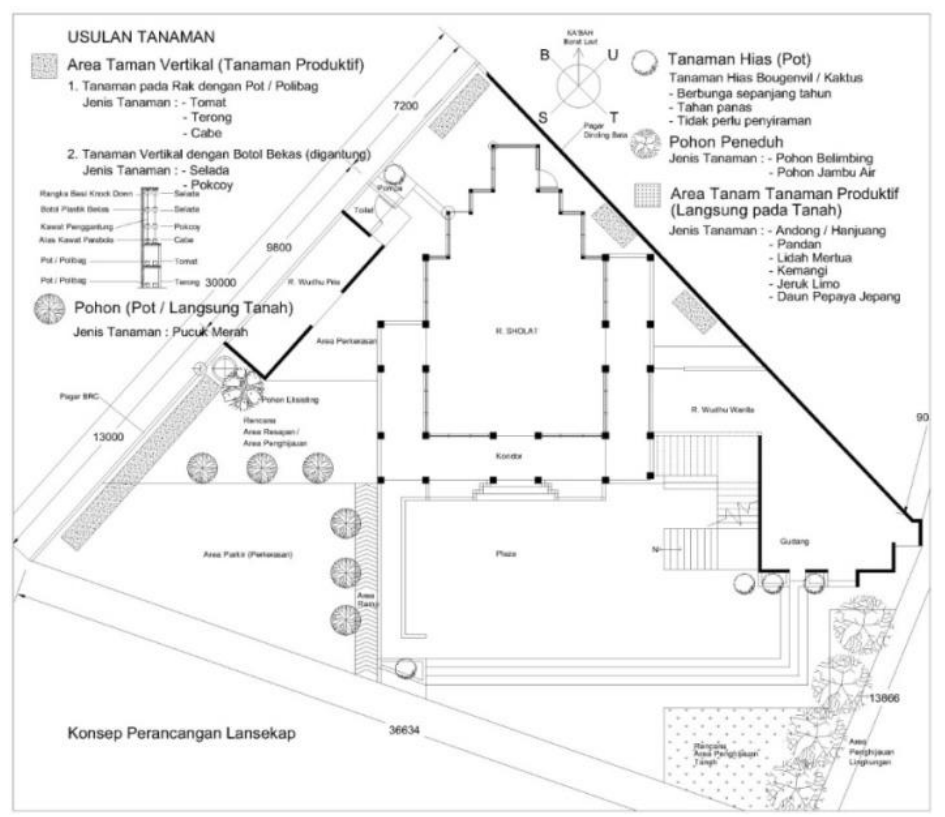

Gambar 8. Usulan Jenis dan Letak Tanaman (Sumber: Dokumentasi pribadi)
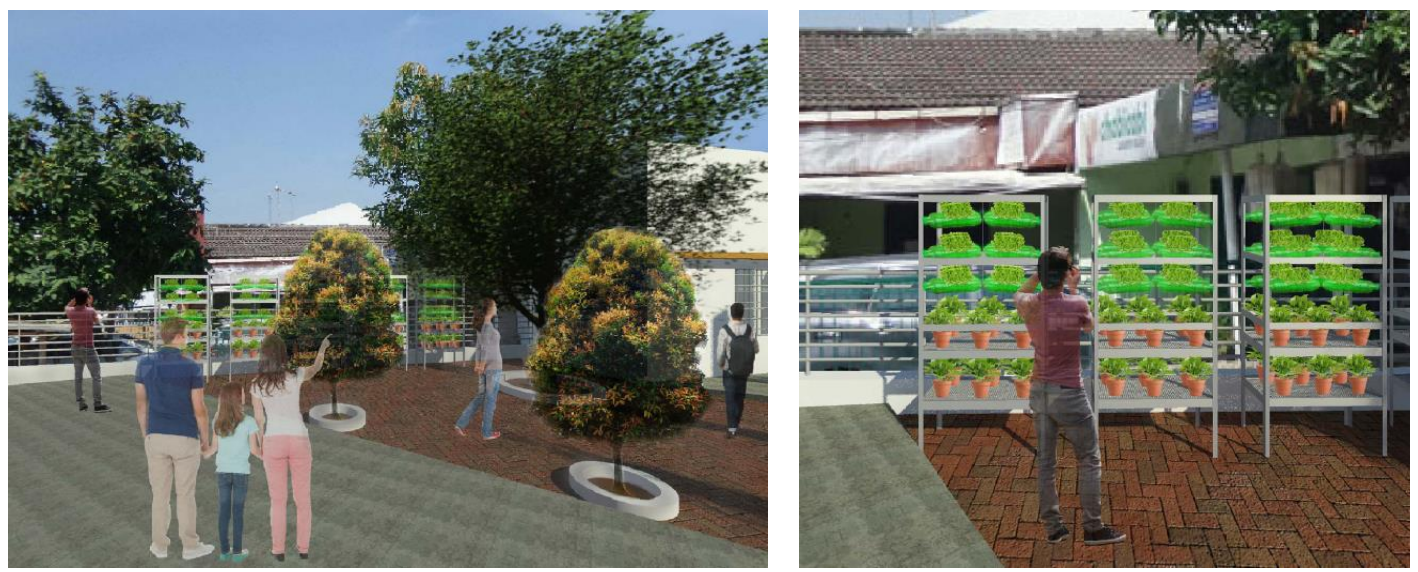

Gambar 9. Imaji Lansekap Masjid Darul Ihsan

(Sumber: Dokumentasi Pribadi)

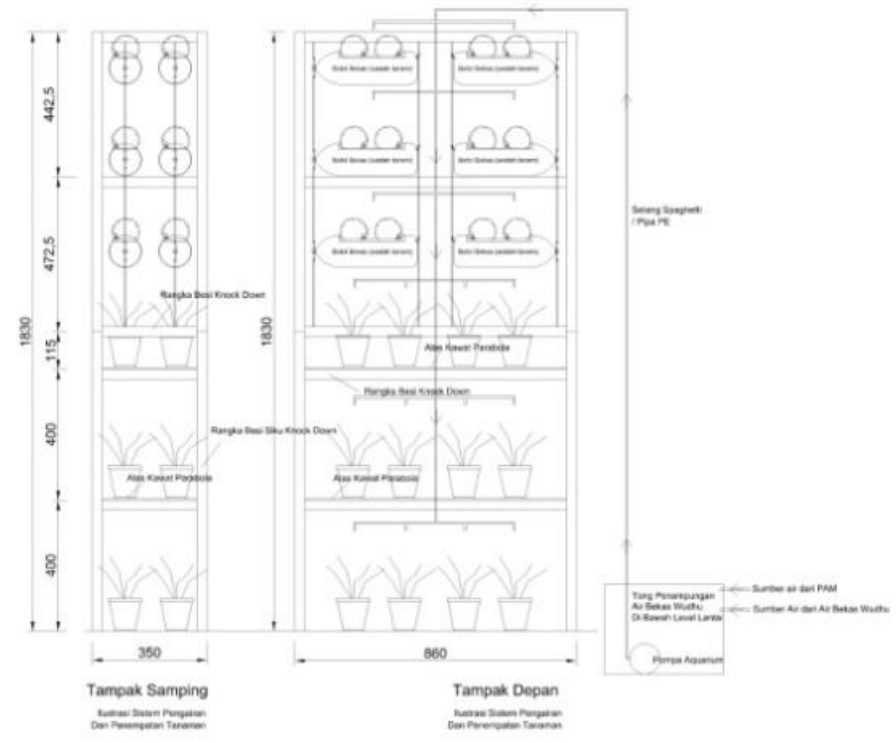




\section{Gambar 10. Rencana Rak Tanam Vertikultur}

(Sumber : Dokumentasi pribadi)
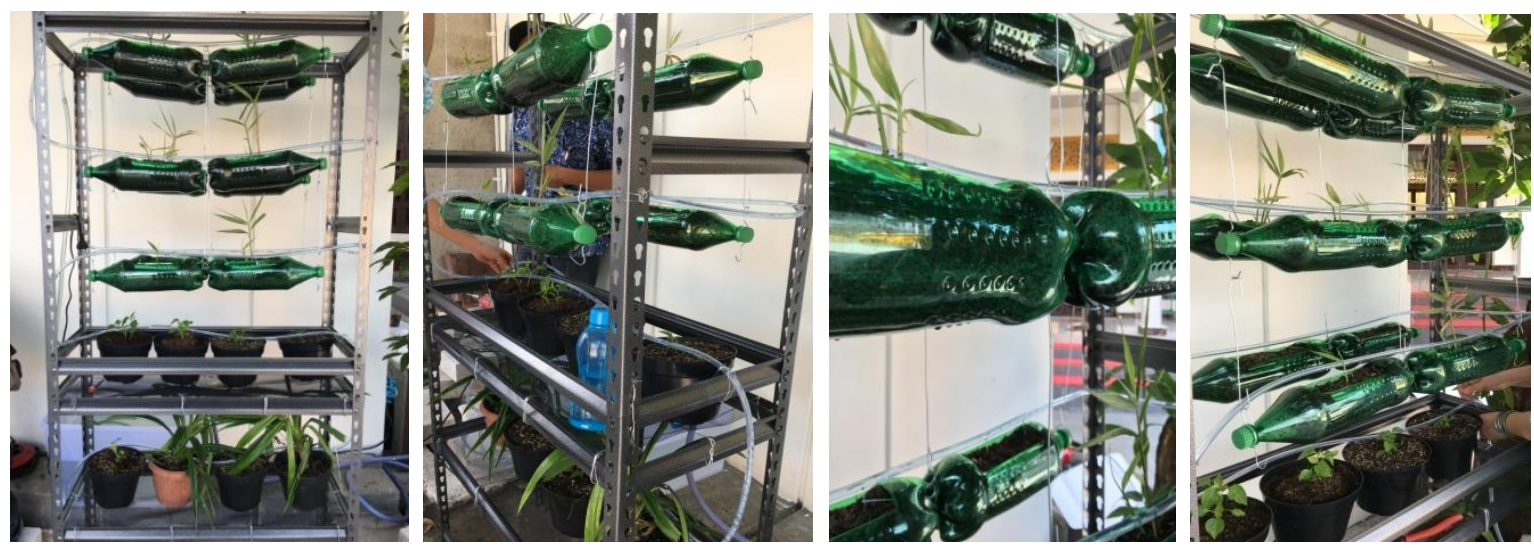

Gambar 11. Hasil Percontohan Tanaman dengan Sistem Vertikultur

\section{Pembahasan Hasil PKM:}

Kondisi lapangan dalam hal ini halaman masjid Darul Ihsan sangat dominan bidang perkerasannya, dan ruang terbuka yang dapat ditanami sekitar $20 \%$. Sehingga pengembangan tanaman hijau tidak hanya di lahan terbuka, tetapi juga memaksimalkan bidang-bidang vertikal yang diupayakan menjadi media tanam, dengan teknik vertikultur. Sebagai bagian dari fasilitas masjid, taman di halaman masjid diharapkan tidak hanya berfungsi sebagai penghijauan dan estetika, melainkan diharapkan dapat memberikan manfaat ekonomis bagi pengelola masjid. Sehingga pemilihan jenis tanaman diutamakan tanaman produktif yang menghasilkan. Beberapa hal yang perlu mendapat perhatian untuk mendapatkan kualitas taman yang baik adalah:

- Aspek pemeliharaan tanaman, karena tanaman adalah mahluk hidup yang mempunyai kebutuhan pengairan dan nutrisi/pupuk yang baik serta perlu pembersihan dari hama/gulma tanaman

- Memahami daur hidup tanaman/tumbuhan yang spesifik untuk setiap jenisnya, meliputi proses tumbuh, berkembang/berbuah, tua dan mati. Sehingga perlu perawatan secara berkesinambungan dan pada waktu-waktu tertentu memerlukan peremajaan/pergantian tanaman.

\section{KESIMPULAN}

Perencanaan lansekap masjid perlu disesuaikan dengan kondisi lahan/area tanam yang memungkinkan. Mengingat ruang terbuka masjid Darul Ihsan sudah diperkeras hingga 80\%, maka area tanam dapat menggunakan bidang dinding vertikal yang mendapat sinar matahari cukup. Terdapat banyak sistem yang mendukung dibuatnya kebun vertikal, dengan semaksimal mungkin menggunakan air sisa wudhu untuk penyiraman dan daur ulang bahan bekas untuk wadah media tanam. Tanaman yang dipilih sebaiknya mempunyai fungsi produktif seperti tanaman budidaya dan tanaman obat.

Respon masyarakat dan jamaah masjid cukup antusias, hal tersebut terlihat saat kegiatan pemasangan rak tanaman vertikultur berlangsung, banyak warga tertarik untuk mempelajari teknik yang relatif baru bagi mereka. Pihak DKM/pengurus masjid juga menerima dengan baik kegiatan ini dan berharap tahap selanjutnya yaitu percontohan tanaman hidroponik dapat dilakukan segera. Kegiatan PKM ini selain menghasilkan rancangan lansekap secara keseluruhan yang disesuaikan dengan kondisi eksisting, diharapkan juga dapat mendukung kegiatan masjid. Selain itu desain instalasi dan rak untuk tanaman vertikal, juga menghasilkan 
contoh penerapan cara tanam sistem vertikultur, yang bisa menambah wawasan masyarakat sekitar.

\section{Ucapan Terima Kasih}

Dengan selesainya kegiatan PKM Perencanaan Lansekap Masjid Darul Ihsan, Tim PKM dari Jurusan Arsitektur mengucapkan terima kasih kepada para pihak yang telah memungkinkan pelaksanaan kegiatan ini yaitu: DPPM Untar selaku pemberi dana hibah internal, Bapak Agung dan Bapak Herman selaku wakil pengurus Masjid Darul Ihsan, serta Ibu Samsu Hendra Siwi selaku pengurus RW di Pondok Pekayon Indah Bekasi, yang telah memberikan dukungan sehingga rangkaian kegiatan ini berhasil dilaksanakan.

\section{REFERENSI}

Anggraini, D. (2010). Kampung Hijau, Suatu Alternatif Meningkatkan Kualitas Lingkungan di Kawasan Perkotaan, Prosiding Seminar Internasional Green Building, 28 Oktober 2010. Universitas Tarumanagara. Jakarta.

Kusmiati A. dan Solikhah U. (2015). Peningkatan Pendapatan Keluarga Melalui Pemanfaatan Pekarangan Rumah Dengan Menggunakan Teknik Vertikultur. Jurnal Inovasi dan

Kewirausahaan Vol 4, No 2, Mei 2015 hal. 94-101

Lukman, L. (2018). Balai Penelitian Tanaman Sayuran dalam http://sahabatpetani.com /2018/01/11/budidaya-sayur-vertikultur-untuk-lahan-sempit-masyarakat-kota. Wikipedia. Islamic garden en.m.wikipedia.org

Manfaat Penghijauan bagi Lingkungan, Harian Jurnal Asia. www.jurnalasia.id April 7, 2015.

Morrison S. \& Sweet R. 2008. Garden Up, Smart Vertical Gardening for Small and Large Spaces. Coolspringpress, Brenwood, Tennessee.

Nabila, C.A. et.al. (2018). Alternatif Pohon Buah untuk Penghijauan Permukiman Perkotaan Berdasarkan Pendugaan Tingkat Keindahan dan Pendapat Masyarakat di Kelurahan

Rejowinangun, Yogyakarta. Jurnal Vegelatika. ISSN 2302-4054. Vol 7, No 1, 2018

Purnomo Hadi, N. 2006. dalam Buku; Ruang Terbuka Hijau Sebagai Unsur Utama Tata Ruang Kota. Direktorat Jenderal Penataan Ruang, Departemen Pekerjaan Umum.

Tan, C.L. et al. Plant Selection and Placement Criteria for Landscape Design. Dalam T.H. Karyono et.al. (editor), Sustainable Building and Built Environment to Mitigate Climate Change in the Tropics, Springer International Publishing AG 2017 hal 249-259.

Thohir, K.A (1985). Butir-butir Tata Lingkungan Sebagai Masukan Untuk Arsitektur Lansekap dan Pembangunan Berwawasan Lingkungan. P.T. Bina Aksara, Jakarta

Wilson, Tony. (2016). The Essential Organic Gardening Guide Book. 